\section{Notaire}

Vol. 4 No. 1, Februari 202
e-ISSN: 2655-9404

p-ISSN: 2721-8376

DOI: $10.20473 /$ ntr.v4i1.24845

Article history: Submitted 19 January 2021; Accepted 29 January 2021; Available online 1 February 2021.

\title{
Tanggung Gugat Pra Kontrak Transaksi Jual Beli Berdasar Negosiasi dengan Itikad Buruk
}

\author{
Julienna Hartono \\ hartonojulienna@yahoo.com \\ Universitas Airlangga
}

\begin{abstract}
Article 1338 (3) BW implicitly regulates the obligations of good faith during negotiations. But still, there are problems regarding good faith in contract law; the abstraction of its meaning and scope. This problem is caused by the lack of legal rules, especially in BW. As a result, many parties suffer losses during the negotiation stage, but there is no legal protection for them. Whereas, other nations have recognized pre-contractual liability, namely the obligation for parties with bad faith during negotiations to pay compensation. The method used in this legal research is legal construction and deductive reasoning. The analysis shows that the criteria for bad faith during the sale and purchase negotiations can be derived from the doctrines and principles of international law. Also, part of the pre-contractual liability doctrine has been regulated in $B W$ (regarding the cancellation of the contract), the remaining can sue based on unlawful acts, or breach of contract (if stipulating detailed rights and obligations in the preliminary agreement).

Keywords: Pre-Contractual Liability; Good Faith; Negotiation; Contract Law.
\end{abstract}

$\frac{\text { Abstrak }}{\text { Pasal 1338(3) BW secara tersirat mengatur kewajiban itikad baik selama negosiasi. }}$ Walaupun terdapat aturan hukumnya, masih terdapat masalah dengan itikad baik dalam hukum kontrak; makna dan ruang lingkupnya yang abstrak. Masalah tersebut disebabkan oleh minimnya aturan hukum tentang itikad baik dalam hukum kontrak, terutama dalam BW. Akibatnya, banyak pihak yang dirugikan selama tahap negosiasi, namun tidak ada perlindungan hukum bagi pihak yang dirugikan tersebut. Di sisi lain, hukum nasional lain telah mengenal tanggung gugat prakontrak, yaitu kewajiban bagi pihak yang beritikad buruk selama negosiasi untuk membayar ganti kerugian. Metode yang digunakan dalam penelitian hukum ini adalah konstruksi hukum dan penalaran deduktif. Hasil analisa menunjukkan bahwa kriteria itikad buruk selama negosiasi jual beli dapat diperoleh dari doktrin-doktrin dan prinsip hukum internasional. Selain itu, sebagian doktrin tanggung gugat pra kontrak telah diatur dalam BW, sepanjang mengenai pembatalan kontrak, selebihnya pihak yang dirugikan dala tahap negosiasi dapat menggugat berdasarkan perbuatan melanggar hukum, atau wanprestasi (jika mengatur hak dan kewajiban secara rinci dalam perjanjian pendahuluan).

Kata Kunci: Tanggung Gugat Pra Kontrak; Itikad Baik; Negosiasi; Hukum Kontrak. 


\section{Pendahuluan}

"Until the contract is signed, nothing is real". ${ }^{1}$ (Sampai kontrak ditandatangani, tidak ada yang nyata). Ungkapan tersebut banyak dijadikan prinsip oleh para pelaku bisnis. Seringkali ditemui pihak yang beritikad buruk selama negosiasi kontrak, karena menganggap dirinya belum terikat dengan satu sama lain. Tentu tindakan ini dapat merugikan lawan pihak dalam negosiasi.

Penelitian ini difokuskan pada salah satu kontrak yang sangat esensial yaitu jual beli, mengingat jenis kontrak dalam praktik tidak terhitung jumlahnya. Definisi jual beli diatur dalam Pasal 1457 BW, yaitu suatu kontrak dimana pihak yang satu mengikatkan dirinya untuk menyerahkan suatu kebendaan, dan pihak lain mengikatkan dirinya untuk membayar harga yang telah dijanjikan. Berdasarkan Pasal 1458 BW, jual beli merupakan kontrak konsensuil, dimana kontrak jual beli terjadi saat para pihak mencapai kesepakatan mengenai barang dan harga. Kesepakatan (toesteming) didefinisikan sebagai persesuaian kehendak yang ditandai dengan penerimaan terhadap penawaran. ${ }^{2}$ Namun, mengenai konsensualisme dalam jual beli ini terdapat pengecualian, yaitu dalam hal kontrak formal $^{3}$ dan kontrak dengan syarat tangguh. ${ }^{4}$

Kontrak jual beli terjadi ketika para pihak mencapai kesepakatan. Adapun sebelum mencapai kesepekatan para pihak terlebih dahulu melalui proses negosiasi. ${ }^{5}$ G.O. Faure dan G. Sjostedt mendefinisikan negosiasi sebagai proses pengambilan keputusan bersama, dimana para pihak mengakomodasi kepentingan mereka yang berbeda menjadi keputusan yang dapat diterima

1 Brainy Quote, 'Glenn Danzig Quotes' (Brainy Quote, 2020)<https://www.brainyquote. com/quotes/glenn_danzig_274256> diakses pada tanggal 13 Oktober 2020.

2 Erni Agustin, The Duty of Good Faith and Pre-Contractual Liability (A Comparative Study) (Airlangga University Press 2013).[44].

3 Kontrak semacam ini juga disebut kontrak formal, dimana tidak cukup dengan adanya kesepakatan antara para pihak, tetapi kontrak jual beli baru terjadi setelah dibuat dalam bentuk formalnya, sesuai ketentuan perundang-undangan yang mengatur, lihat Subekti, Aneka Perjanjian, Cet.XI (Citra Aditya Bakti 2014) (selanjutnya disingkat Subekti II).[4].

4 Pasal 1253 BW mengatur perikatan dengan syarat tangguh, yaitu terjadinya perikatan digantungkan pada terjadinya atau tidak terjadinya suatu peristiwa di kemudian hari

5 Natsir Asnawi, Aspek Hukum Janji Prakontrak: Telaah dalam Kerangka Pembaruan Hukum Kontrak di Indonesia (UII Press 2017).[22]. 
bersama. ${ }^{6}$ Proses negosiasi ini disebut tahap pra kontrak. ${ }^{7}$ Dengan demikian tahap pra kontrak merupakan tahap yang sangat penting dalam pembentukan kontrak karena menentukan terbentuk atau tidaknya suatu kontrak. ${ }^{8}$

Para pihak senantiasa mengeluarkan biaya selama proses negosiasi, misalnya biaya perjalanan, biaya pengacara, dll. ${ }^{9}$ Bahkan, selama negosiasi, tidak menutup kemungkinan lawan pihak melakukan perbuatan hukum, misalnya menjual assetnya, berhutang, dll. ${ }^{10}$ Tentu jika negosiasi gagal, maka pihak yang telah mengeluarkan biaya yang besar selama negosiasi mengalami kerugian.

Kerugian dalam negosiasi dapat diakibatkan niat buruk salah satu pihak dalam negosiasi. Tidak semua pihak dalam negosiasi memiliki tujuan untuk menutup perjanjian, tidak jarang satu atau lebih pihak dalam negosiasi memiliki intensi lain, misalnya agar lawan pihak dalam negosiasi kehilangan kesempatan untuk bernegosiasi dengan pelaku usaha lain, atau semata-mata untuk memperoleh keuntungan dari lawan pihak. ${ }^{11}$

Situasi diatas digambarkan oleh putusan Mahkamah Agung nomor 2609 K/Pdt/2014 antara Ignatius Igor (II), Nurhartini (N) dan Vici Jaya (VJ) melawan Ervin Alexander (EA), dimana EA dengan II, N serta VJ sedang dalam tahap negosiasi untuk jual beli tanah. Para pihak memutuskan untuk menuangkan halhal yang telah disepakati dalam Memorandum of Understanding (MoU). Namun II, $\mathrm{N}$ dan VJ menunda-nunda penandatanganan $\mathrm{MoU}$, dan kemudian baru diketahui bahwa mereka telah menjual tanah tersebut ke pihak ketiga. Lebih parahnya lagi, walaupun telah menjual tanah ke pihak ketiga, II, N dan VJ masih melanjutkan negosiasi dengan EA sebelum akhirnya mengakui bahwa objek tanah telah

\footnotetext{
${ }^{6}$ Claude Alavoine, Ferkan Kaplanseren dan Frederic Teulon, 'Teaching (and Learning) Negotiation: Is There Still A Room for Innovation?' (2014) 18 International Journal of Management \& Information System.[1].

7 Sogar Simamora, Hukum Kontrak: Prinsip-Prinsip Hukum Kontak Pengadaan Barang dan Jasa Pemerintah di Indonesia (LaksBang PRESSindo 2017).[192].

8 Natsir Asnawi, Op.Cit.[33].

9 Taryana Soenandar, Prinsip-Prinsip UNIDROIT sebagai Sumber Hukum Kontrak dan Penyelesaian Sengketa Bisnis Internasional, Cet.I (Sinar Grafika 2004).[108].

${ }^{10}$ Natsir Asnawi, Op.Cit.[22].

11 Julija Kirsiene dan Natalja Leonova, 'Qualification of Pre-Contractual Liability and The Value of Loss Opportunity as A Form of Losses' (2009) 1 Jurisprudencija.[238].
} 
dialihkan ke pihak ketiga.

Awalnya, prinsip kebebasan berkontrak lebih dikedepankan, dimana para pihak bebas untuk memulai dan mengakhiri negosiasi. ${ }^{12}$ Namun karena seringkali ada pihak yang mengalami kerugian selama negosiasi, maka kebebasan berkontrak itu dibatasi oleh kewajiban itikad baik dalam negosiasi. ${ }^{13}$ Titik tolak kewajiban itikad baik dalam negosiasi adalah ketika Von Jhering mengenalkan doktrin culpa in contrahendo. ${ }^{14}$ Von Jhering menyatakan bahwa: "damages should be recoverable against the party whose blameworthy conduct during negotiations for a contract brought about its invalidity or prevented its perfection". ${ }^{15}$ (Kerugian harus dipulihkan oleh pihak yang melakukan perilaku tercela selama negosiasi yang menyebabkan sebuah kontrak tidak sah atau mencegah kesempurnaanya). Kemudian doktrin tersebut dikembangkan oleh Raymond Salleiles. Raymond Salleiles menyatakan bahwa setelah para pihak masuk tahap negosiasi, para pihak wajib beritikad baik dan tidak dapat menarik diri dari negosiasi secara sepihak tanpa membayar kompensasi. ${ }^{16}$

Indonesia sendiri telah mengenal kewajiban itikad baik dalam negosiasi. ${ }^{17}$ Prinsip ini tersirat dalam Pasal 1338(3) BW: "Suatu perjanjian harus dilaksanakan dengan itikad baik". Dalam bukunya berjudul "Itikad Baik dalam Kebebasan Berkontrak", Ridwan Khairandy menulis bahwa walaupun Pasal 1338(3)BW mengatur itikad baik hanya pada tahap pelaksanaan kontrak, namun harus dimaknai kewajiban beritikad baik dimulai sejak tahap pra kontrak hingga pelaksanaan kontrak..$^{18}$

12 ibid.[225].

13 Ridwan Khairandy, Itikad Baik dalam Kebebasan Berkontrak, Cet.II (Fakultas Hukum Universitas Indonesia 2004).[125].

${ }^{14}$ Rodrigo Novoa, 'Culpa in Contrahendo: A Comparative Law Study: Chilean Law and The United Nations Convention on Contracts for The International Sales of Goods' (2005) 22 Arizona Journal of International and Comparative Law.[584].

15 ibid.

16 ibid.

17 Ichsania Saputri, 'Doktrin Culpa in Contrahendo (Prinsip dan Penerapannya dalam Tanggung Gugat Hubungan Pra-Kontraktual)', Skripsi (Program Sarjana Universitas Airlangga, 2013).[61].

18 Leonora Bakarbessy dan Ghansam Anand, Buku Ajar Hukum Perikatan (Zifatama Jawara 2018).[150-151]. 
Walaupun telah diakui secara universal, masih terdapat masalah terkait itikad baik dalam negosiasi. Permasalahannya terdapat pada makna dan lingkup dari prinsip itikad baik dalam negosiasi yang masih belum jelas. ${ }^{19}$ Indonesia juga masih sangat kuat dipengaruhi oleh hukum kontrak klasik yang hanya menerapkan itikad baik pada tahap pelaksanaan kontrak..$^{20}$ Selain itu, dilihat dari segi legislasinya, BW belum mengatur mengenai tahap pra kontrak. ${ }^{21}$ Dengan demikian, penerapan asas itikad baik dalam negosiasi masih sangat bergantung pada interpretasi hakim.

Karena konsep itikad baik masih bermasalah, tidak ada kepastian dan perlindungan hukum bagi para pihak yang dirugikan dalam tahap negosiasi. Padahal hukum seharusnya membawa keadilan, kepastian hukum, dan kemanfaatan. ${ }^{22}$ Oleh karena itu, penulis akan melakukan penelitian mengenai tanggung gugat pra-kontrak dalam jual beli atas dasar negosiasi dengan itikad buruk. Adapun dua pokok pembahasan adalah: 1) kriteria itikad buruk dalam negosiasi jual beli, dan 2) akibat hukum bagi pihak yang beritikad buruk dalam negosiasi kontrak jual beli sehingga merugikan pihak lain.

\section{Kriteria Negosiasi dengan Itikad Buruk dalam Kontrak Jual Beli}

Itikad baik terdiri atas itikad baik dalam arti subjektif dan objektif. Dalam hukum kontrak, itikad baik yang digunakan adalah itikad baik dalam arti objektif yang secara sempit berarti kerasionalan dan kepatutan (redelijkheid dan billijkheid atau reasonable and fairness), dan secara luas berarti para pihak dalam kontrak senantiasa bertindak sesuai dengan kebiasaan sosial yang ada. ${ }^{23}$ Itikad baik dalam hukum kontrak diatur dalam pasal 1338 (3) BW dan dilengkapi dengan Pasal 1339 BW. Adapun Pasal 1339 BW mengatur bahwa suatu kontrak tidak hanya mengikat

\footnotetext{
19 Ridwan Khairandy, Op.Cit.[129].

${ }^{20}$ Suharnoko, Hukum Perjanjian: Teori dan Analisa Kasus, Cet.III, Edisi I (Grafika 2004).[3].

${ }_{21}$ Natsir Asnawi, Op.Cit.[29].

${ }^{22}$ Faizal Kurniawan [et al.], 'Unsur Kerugian dalam Unjust Enrichment untuk Mewujudkan Keadilan Korektif (Corrective Justice)' (2018) 33 Yuridika.[2].

${ }^{23}$ Ridwan Khairandy, Op.Cit.[309].
} 
express term, tapi termasuk juga implied term.

Itikad baik tahap pra kontrak diprakarsai oleh doktrin culpa in contrahendo. Doktrin tersebut pertama kali diungkapkan pada tahun 1861 oleh Von Jhering: "that damages should be recoverable against the party whose blameworthy conduct during negotiations for a contract brought about its invalidity or prevented its perfection". ${ }^{24}$ (kerugian harus ditagih terhadap pihak yang berperilaku tercela selama negosiasi kontrak, menyebabkan ketidakabsahannya atau menghalangi kesempurnaannya).

Doktrin culpa in contrahendo awalnya hanya fokus pada cacat kehendak dalam pembentukan kontrak. Doktrin tersebut tidak pernah diterapkan dalam kondisi negosiasi yang gagal. Tokoh yang mengembangkan doktrin culpa in contrahendo adalah Raymond Salleiles, yang menyatakan bahwa setelah para pihak masuk tahap negosiasi, para pihak wajib beritikad baik dan tidak dapat menarik diri dari negosiasi secara sepihak tanpa membayar kompensasi atas reliance damage. ${ }^{25}$ Sehingga, kewajiban itikad baik selama negosiasi bertujuan untuk membatasi kebebasan berkontrak. ${ }^{26}$

Doktrin culpa in contrahendo juga semakin berkembang setelah adanya putusan Hoge Raad dalam perkara Plas vs Valburg. Dalam putusannya, Hoge Raad membagi proses negosiasi menjadi 3 tahap: ${ }^{27}$

a. Tahap pertama: tahap awal negosiasi (initial stage of negotiaion)

Pada tahap ini, para pihak memiliki hak untuk memutus negosiasi kapanpun tanpa membayar ganti rugi,

b. Tahap kedua: tahap pertengahan (intermediary)

Pada tahap ini para pihak memiliki hak untuk memutus negosiasi, namun wajib mengganti biaya yang telah dikeluarkan oleh pihak lain.

c. Tahap ketiga: tahap akhir (final stage)

Pada tahap ini para pihak tidak dapat memutus negosiasi tanpa alasan yang

\footnotetext{
${ }^{24}$ Rodrigo Novoa, Op.Cit.[584].

25 ibid.

${ }^{26}$ Ridwan khairandy,Op.Cit.[264].

27 Arthur S. Hartkamp, Contract Law in the Netherlands, Edisi II (Kluwer Law International 2015).[80].
} 
jelas karena pada tahap ini, para pihak sewajarnya telah memiliki ekspektasi bahwa kontrak akan terbentuk. Sehingga pihak yang memutus negosiasi tanpa alasan yang jelas wajib membayar kompensasi atas kerugian yang dialami pihak lain dalam negosiasi tersebut.

Yang menarik dari putusan Hoge Raad dalam perkara Plas vs Valburg adalah mengenai tolak ukur negosiasi telah mencapai tahap ketiga dan ganti kerugiannya. Tolak ukur yang digunakan untuk mengetahui apakah negosiasi telah mencapai tahap ketiga adalah ketika "the parties, from both side, could trust that some contract would, in any case, ensue from the negotiation". ${ }^{28}$ (para pihak, dari kedua belah pihak, dapat mempercayai bahwa kontrak, dalam hal apapun, dapat dihasilkan dari negosiasi). Kemudian mengenai ganti rugi, putusan Plas vs Valburg adalah putusan Hoge Raad yang mewajibkan pihak yang bertanggung gugat untuk membayar kerugian berupa keuntungan yang diharapkan (expectation interest). ${ }^{29}$

Itikad baik tahap pra kontrak di Indonesia diatur secara tersirat dalam Pasal 1338(3) BW. Namun pasal tersebut tidak memberikan definisi maupun kriteria dari itikad. Oleh karena itu untuk memperoleh kriteria itikad buruk dalam negosiasi kontrak jual beli perlu dianalisa beberapa sumber:

a. Doktrin Von Jhering

Von Jhering juga membuat kriteria negosiasi dengan itikad buruk, yang terdiri atas: $:^{30}$

1. Menyepakatikontraktidaksah, walaupunmengetahuiketidakabsahannya;

2. Tidak serius dalam membuat suatu penawaran;

3. Melakukan kesalahan dalam menyampaikan penawaran;

4. Mengetahui atau seharusnya mengetahui ketidakmungkinan pelaksanaan suatu kontrak.

b. Cacat kehendak

Cacat kehendak termasuk dalam kriteria negosiasi dengan itikad buruk karena awalnya kewajiban itikad baik tahap negosiasi diterapkan dalam hal

\footnotetext{
${ }^{28}$ Ridwan Khairandy,Op.Cit.[257].

29 ibid.

30 ibid.[261].
} 
50 | Julienna Hartono: Tanggung Gugat Pra...

terdapat cacat kehendak. Berdasarkan Pasal 1321 BW, cacat kehendak terdiri atas:

1. Kekhilafan;

2. Paksaan;

3. Penipuan.

Ada satu lagi bentuk cacat kehendak yang belum diatur dalam BW, namun telah diterima secara doktrin, yaitu penyalahgunaan keadaan (Misbruik van Omstandigheden). Unsur dari penyalahgunaan keadaan adalah: 1) kerugian bagi salah satu pihak, dan 2) penyalahgunaan kesempatan oleh lawan pihak yang terdiri atas penyalahgunaan keunggulan ekonomi dan/atau kejiwaan. ${ }^{31}$

c. Doktrin Bundesgerichtshof

Bundesgerichtshof yang menyatakan bahwa itikad buruk dalam negosiasi ketika salah satu pihak menghentikan negosiasi dan tindakan tersebut merugikan lawan pihak. ${ }^{32}$ Doktrin ini telah diterapkan dalam putusan Plas vs Valburg.

d. Doktri Ridwan Khairandy

Dalam bukunya berjudul “Itikad Baik dalam Kebebasan Berkontrak”, Ridwan Khairandy menulis bahwa itikad baik tahap pra kontrak diwujudkan dengan kewajiban para pihak untuk menjelaskan dan meneliti fakta material (duty to disclose and duty to care). ${ }^{33}$

e. Principles of European Contract Law (PECL) dan UNIDROIT Principles of International Commercial Contracts (UPICC)

Pasal 2:301 PECL dan Pasal 2.1.15 UPICC mengatur bahwa negosiasi bertentangan itikad baik jika salah satu atau para pihak memasuki atau melanjutkan negosiasi tanpa bermaksud untuk mencapai kontrak dengan lawan pihak. Selain itu komentar dalam UPICC menyatakan bahwa kriteria lain negosiasi itikad buruk adalah jika salah satu pihak secara lalai atau

\footnotetext{
${ }^{31}$ Leonora Bakarbessy dan Ghansam Anand, Op.Cit.[120].

32 Ridwan Khairandy, Op.Cit.[261].

33 ibid.[275].
} 
sengaja menyesatkan lawan pihak, baik mengenai sifat maupun ketentuan dalam kontrak, dengan cara salah menjelaskan fakta material, atau tidak mengungkapkan fakta material yang sekiranya wajib diketahui lawan pihak. Pasal 2:302 PECL dan Pasal 2.1.16 UPICC juga mengatur itikad buruk dalam negosiasi berupa pelanggaran atas duty of confidentiality.

f. Perkembangan doktrin culpa in contrahendo

Beberapa negara telah mengenal dan mengakui itikad buruk dalam negosiasi berupa penundaan penandatanganan kontrak yang merugikan lawan pihak (delay in concluding contract). ${ }^{34}$ Misalnya penjual yang menunda jual beli rumah sampai pembeli kehilangan keuntungan pajak yang dapat diperoleh. ${ }^{35}$

Dari berbagai sumber diatas, maka telah diperoleh kriteria negosiasi dengan itikad buruk dalam jual beli, yang terdiri atas:

a. Penjual dan/atau pembeli menyepakati kontrak yang tidak sah, walaupun mengetahui ketidakabsahan kontrak jual beli;

b. Penjual dan/atau pembeli dengan lalai atau sengaja membuat pernyataan yang menyesatkan lawan pihak;

c. Penjual dan/atau pembeli menggunakan paksaan selama negosiasi;

d. Penjual dan/atau pembeli menggunakan penipuan selama negosiasi;

e. Penjual dan/atau pembeli menyalahgunakan keadaan, baik keunggulan ekonomi maupun kejiwaan;

f. Penjual dan/atau pembeli tidak serius dalam membuat suatu penawaran;

g. Penjual dan/atau pembeli melakukan kesalahan dalam menyampaikan penawaran;

h. Penjual dan/atau pembeli mengetahui atau seharusnya mengetahui ketidakmungkinan pelaksanaan suatu kontrak, namun tetap melanjutkannegosiasi;

i. Penjual atau pembeli menarik diri dari negosiasi ketika negosiasi telah mencapai tahap akhir (final stage) dan tanpa alasan yang jelas;

j. Penjual tidak menjelaskan seluruh fakta material berkaitan dengan jual beli;

k. Pembeli tidak meneliti fakta material berkaitan dengan jual beli;

1. Penjual dan/atau pembeli memasuki atau melanjutkan negosiasi tanpa bermaksud untuk mencapai kontrak dengan lawan pihak;

m. Penjual dan/atau pembeli membocorkan informasi rahasia yang telah diberikan oleh lawan pihak selama negosiasi;

n. Penjual atau pembeli menunda-nunda jual beli (delay in concluding contract).

\footnotetext{
${ }^{34}$ Chuanyang Ding, 'The Doctrine of Precontractual Liability Under Chinese Law : A Comparative Outlook' (2019) 27 European Review of Private Law.[503].

35 ibid.
} 


\section{Akibat Hukum bagi Pihak Yang Beritikad Buruk dalam Negosiasi Kontrak Jual Beli sehingga Merugikan Pihak Lain}

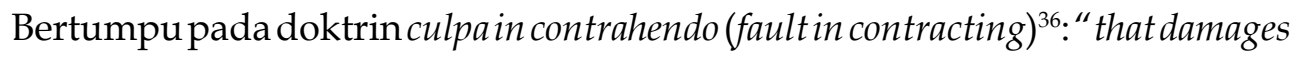
should be recoverable against the party whose blameworthy conduct during negotiations for a contract brought about its in- validity or prevented its perfection" ${ }^{37}$ (kerugian harus ditagih terhadap pihak yang berperilaku tercela selama negosiasi kontrak, menyebabkan ketidakabsahannya atau menghalangi kesempurnaannya), maka akibat hukum bagi pihak yang beritikad buruk selama negosiasi adalah kewajiban membayar ganti kerugian. Kewajiban demikian lazimnya disebut tanggung gugat pra kontrak. Dalam bukunya berjudul "Pengantar Ilmu Hukum”, Peter Mahmud Marzuki menulis bahwa tanggung gugat (liability) mengarah pada kewajiban subjek hukum untuk membayar kompensasi atau ganti rugi yang timbul akibat suatu peristiwa atau tindakan hukum. ${ }^{38}$ Sedangkan tahap pra kontrak adalah tahap pembentukan kontrak yang identik dengan negosiasi. Dengan demikian, tanggung gugat pra kontrak adalah kewajiban mengganti kerugian yang timbul akibat perilaku tercela selama negosiasi. ${ }^{39}$

Unsur- unsur tanggung gugat pra kontrak terdiri atas:1) negosiasi, 2) itikad buruk selama negosiasi, 3) kausalitas, 4) kerugian: ${ }^{40}$

1. Negosiasi

Negosiasi dimulai dengan penawaran dan diakhiri dengan penerimaan. Namun dalam hal tanggung gugat pra kontrak, itikad buruk selama negosiasi mengakibatkan kontrak tidak sah atau negosiasi gagal dan tidak membuahkan kontrak jual beli.

${ }^{36}$ R.J.P Kottenhagen, 'From Freedom of Contract to Forcing Parties to Agreement, Address to the Annual Meeting of the European American Consortium for Legal Education' (European American Consortium for Legal Education 2005).[10].

37 Rodrigo Novoa, Op.Cit.[584].

38 Peter Mahmud Marzuki, Pengantar Ilmu Hukum, Cet.VIII (Kencana 2015) (selanjutnya disingkat Peter Mahmud Marzuki III).[220].

39 "Precontractual liability is liability that arises out of a harmful conduct that occurs during the formation period of a contract." Lihat Najib Hage-Chahine, 'Culpa in Contrahendo in European Private International Law: Another Look at Article 12 of the Rome II Regulation' (2012) 32 Northwestern Journal of International Law and Business.[452].

${ }^{40}$ Rodrigo Novoa, Op.Cit.[589]. 
2. Itikad buruk selama negosiasi

Kriteria itikad buruk selama negosiasi jual beli adalah sebagaimana telah diuraikan pada pembahasan sebelumnya.

3. Kerugian

Unsur terakhir yang harus dipenuhi adalah kerugian. Jenis kerugian dalam hukum kontrak terdiri atas reliance interest dan expectation interest: ${ }^{41}$

a. Reliance interest bertujuan untuk mengembalikan para pihak ke posisi semula sebelum negosiasi. ${ }^{42}$ Kerugian tersebut berupa out of pocket expenses atau pengeluaran nyata selama negosiasi e.g. biaya perjalanan, pendapat ahli, kerugian akibat kehilangan kesempatan bernegosiasi dengan pihak lain (loss of opportunities). ${ }^{43}$

b. Expectation interest bertujuan untuk menempatkan para pihak pada posisi seandainya kontrak terbentuk, berupa keuntungan yang diharapkan atau yang dapat diperoleh. ${ }^{44}$

Kerugian yang dapat dituntut kompensasinya dalam tanggung gugat pra kontrak hanya reliance interest. Argumen untuk mendukung pernyataan tersebut antara lain:

a. Semangat tanggung gugat pra kontrak adalah melindungi harapan yang sah (legitimate expectation) terhadap terbentuknya kontrak, ${ }^{45}$ dan mengganti kerugian salah satu pihak yang mempercayai (reliance) bahwa kontrak akan terbentuk. ${ }^{46}$ Bentuk dan lingkup perlindungan yang diberikan pada tahap pra kontrak tidak dapat disamakan dengan

41 John Y. Gotanda, 'Damages in Lieu of Performance because of Breach of Contract', Working Paper Series pada Villanova University Charles Widger School of Law (Villanova University Charles Widger School of Law 2006).[14].

42 ibid.[14].

${ }^{43}$ Rodrigo Novoa, Op.Cit.[596].

${ }^{44}$ John Y. Gotanda, Op.Cit.[14].

45 Friedrich Kessler dan Edith Fine, 'Culpa in Contrahendo, Bargaining in Good Faith, and Freedom of Contract: a Comparative Study’ (1964) 77 Harvard Law Review.[426].

${ }^{46}$ Rodrigo Novoa, Op.Cit.[598]. 
54 Julienna Hartono: Tanggung Gugat Pra...

kerugian yang diberikan manakala kontrak telah terbentuk. ${ }^{47}$ Sebelum kontrak terbentuk, contract expectation ${ }^{48}$ belum ada, yang ada hanyalah precontractual expectation yang notabene nya tidak sekuat contract expectation. ${ }^{49}$

b. Ganti kerugian berupa expectation interest tidak dapat diberikan karena tujuan tanggung gugat pra kontrak adalah untuk mengganti kerugian pihak yang dirugikan, bukan menghukum pihak yang beritikad buruk..$^{50}$

4. Kausalitas

Kausalitas berarti adanya hubungan sebab akibat antara itikad buruk selama negosiasi dengan kerugian yang dialami. ${ }^{51}$ Teori kausalitas yang dianut adalah teori adequate, dimana kerugian yang dialami merupakan akibat yang langsung dan seketika dari kesalahan..$^{52}$

\section{Kekuatan Mengikat Perjanjian Pendahuluan Menurut Hukum Kontrak Indonesia}

Pembentukan kontrak bisnis seringkali membutuhkan waktu yang lama karena memerlukan beberapa tahap negosiasi (sequenced negotiation). Selama proses negosisi tersebut, para pihak seringkali menyepakati perjanjian pendahuluan. ${ }^{53}$ Oleh karena itu perlu dianalisa mengenai perjanjian pendahuluan, karena akan membawa konsekuensi terhadap tanggung gugat pra kontrak.

Perjanjian pendahuluan (pactum de contrahendo) adalah kesepakatan yang dibuat selama negosiasi untuk mengantisipasi beberapa kesepakatan nanti

${ }^{47}$ John Cartwright dan Martjin W. Hesselink,'Precontractual Liability In European Private Law: Conclusions' (Cambridge University Press ,2008)<https://www.researchgate.net/publication/228218852_Precontractual_Liability_in_European_Private_Law_Conclusions $>$.[2].diakses pada tanggal 5 Desember 2020.

48 ibid [4].

49 ibid.[4-5].

${ }^{50}$ Julija Kirsiene dan Natalja Leonova, Op.Cit.[232].

${ }^{51}$ Leonora Bakarbessy dan Ghansam Anand, Op.Cit.[254].

52 ibid.[239].

${ }^{53}$ Albert H. Choi dan George Triantis, 'Designing and Enforcing Preliminary Agreements' (2020) 3 Texas Law Review.[440]. 
yang akan menjadi puncak dari negosiasi. ${ }^{54}$ Perjanjian pendahuluan seharusnya menjadi dasar penyusunan kontrak di kemudian hari. ${ }^{55}$ Istilah yang digunakan adalah perjanjian pendahuluan karena pada praktiknya digunakan nama yang berbeda-beda e.g. memorandum of understanding (MoU), letter of intent (LoI), head of agreement $(\mathrm{HoA})$, dll. ${ }^{56}$

Adapun tujuan para pihak menyepakati perjanjian pendahuluan adalah untuk melacak perkembangan negosiasi, atau menyepakati kewajiban dan larangan selama negosiasi. Kewajiban dan larangan tersebut dapat berupa kewajiban untuk tidak menyebarkan informasi rahasia (promises of confidentiality), serta larangan untuk negosiasi dengan pihak ketiga selama jangka waktu tertentu (exclusivity). ${ }^{57}$

Dalam BW, tidak terdapat ketentuan mengenai perjanjian pendahuluan. Sehingga mengenai kekuatan mengikatnya mengacu pada Pasal 1320 BW jo. Pasal 1338(1) BW. Pasal 1338(1) BW merupakan dasar eksistensi dari perjanjian pendahuluan, yaitu berdasarkan prinsip kebebasan berkontrak (freedom of contract). Pasal 1320 BW mengatur mengenai keabsahan dari perjanjian pendahuluan yaitu: 1) kesepakatan, 2) kecakapan, 3) objek tertentu, dan 4) causa yang diperbolehkan:

1) Kesepakatan

Dalam suatu perjanjian pendahuluan jual beli, para pihak sepakat untuk membuat kontrak jual beli (agreement to agree), serta menyepakati hal-hal pokok yang akan dinegosiasikan lebih lanjut.

2) Kecakapan

Kecakapan adalah kemampuan subjek hukum untuk melakukan perbuatan hukum secara mandiri. ${ }^{58}$ Subjek hukum terdiri atas individu/perorangan

\footnotetext{
54 E. Allan Fransworth, ‘Precontractual Liability and Preliminary Agreements: Fair Dealing and Failed Negotiations' (1987) 87 Columbia Law Review.[249].

55 H. Salim HS., H. Abdullah, dan Wiwiek Wahyuningsih, Perancangan Kontrak dan Memorandum of Understanding (MoU), Cet.IV (Sinar Grafika 2008).[46].

${ }^{56}$ E. Allan Fransworth, Op.Cit.[249-250].

57 Albert H. Choi dan George Triantis, Op.Cit.[459].

${ }^{58}$ J.H. Nieuwenhuis, Pokok-Pokok Hukum Perikatan (terjemahan Djasadin Saraghi) (Universitas Airlangga 1985).[20].
} 
56 Julienna Hartono: Tanggung Gugat Pra...

dan badan hukum. Pasal 1330 BW mengatur mengenai individu/perorangan yang tidak cakap, yaitu orang yang belum dewasa, dan/atau dibawah pengampuan. Yang dimaksud orang belum dewasa adalah orang yang belum mencapai 18 tahun atau belum kawin. Sedangkan yang dianggap orang dibawah pengampuan adalah orang yang boros, lemah akal budi, dan kekurangan daya berpikir. (vide. Pasal. 433 BW)

Kemudian kecakapan badan hukum ditentukan berdasarkan wewenang organ badan hukum yang bersangkutan. Yang berwenang mengurus dan mewakili Perseroan Terbatas adalah direksi (vide. Pasal 1 angka 5 UndangUndang Nomor 40 Tahun 2007 tentang Perseroan Terbatas sebagaimana telah diubah dengan Undang-Undang Nomor 11 Tahun 2020 tentang Cipta Kerja). Untuk badan hukum yayasan dan koperasi, yang berwenang mengurus dan mewakili yayasan adalah organ pengurus (vide. Pasal 35 Undang-Undang Nomor 28 Tahun 2004 tentang Perubahan Undang-Undang Nomor 16 Tahun 2001 tentang Yayasan jo. Pasal 1 angka 7 Undang-Undang Nomor 17 Tahun 2012 tentang Perkoperasian).

3) Objek tertentu

Objek yang dimaksud disini adalah hak dan kewajiban para pihak. Hak dan kewajiban yang disepakati harus jelas, dapat dihitung dan dapat ditentukan jenisnya (vide. Pasal 1333 BW). Jika sifat serta luas hak dan kewajiban para pihak tidak dapat ditentukan, maka hal tersebut adalah tidak mengikat. ${ }^{59}$

Sebagaimana telah dijelaskan diatas, salah satu ciri dari perjanjian pendahuluan adalah hanya berisikan hal- hal pokok. Dengan kata lain, hak dan kewajiban para pihak belum ditentukan secara jelas. Oleh karena itu, perjanjian pendahuluan tidak memenuhi syarat sah kontrak berupa objek tertentu.

4) Causa yang diperbolehkan

Yang dimaksud causa adalah tujuan para pihak menutup kontrak (kausa finalis). Adapun tujuan para pihak membuat perjanjian pendahuluan adalah

\footnotetext{
59 Agus Yudha Hernoko, Hukum Perjanjian: Asas Proporsionalitas dalam Kontrak Komersial, Cet. IV (Prenadamedia Group 2014).[192].
} 
untuk melacak perkembangan negosiasi, sekaligus sebagai landasan dalam membuat kontrak yang sesungguhnya di kemudian hari.

Dari analisis keabsahan kontrak berdasarkan Pasal 1320 BW, perjanjian pendahuluan tidak memenuhi syarat sahnya kontrak berupa objek tertentu. ${ }^{60}$ Dengan demikian perjanjian pendahuluan tidaklah mengikat para pihak secara hukum, namun sebatas ikatan moral, yaitu niatan untuk merealisasikan kontrak di kemudian hari. ${ }^{61}$ Walaupun para pihak menyepakati bahwa suatu perjanjian pendahuluan mengikat satu sama lain, namun pada prinsipnya tetap belum lahir perjanjian, dan dengan demikian belum lahir hak dan kewajiban pula.

Telah diketahui bahwa perjanjian pendahuluan sifatnya tidak mengikat para pihak, namun jika menemui suatu perjanjian pendahuluan, perlu dianalisis substansinya. Seringkali ditemui ketidaksesuaian antara judul dengan substansi; judulnya adalah perjanjian pendahuluan namun substansinya telah mengatur hak dan kewajiban secara jelas. ${ }^{62}$ Dalam hal demikian, maka perjanjian pendahuluan tersebut dianggap sebagai kontrak sesungguhnya dan mengikat para pihak, ${ }^{63}$ kecuali jika para pihak secara tegas menyatakan bahwa dirinya tidak berniat untuk terikat sampai kontrak sesungguhnya telah ditandatangani. Contoh klausula tersebut antara lain "not binding until final agreement is executed", dan klausul sejenis lainnya. ${ }^{64}$

\section{Tanggung Gugat Pra Kontrak dalam Kerangka Hukum Indonesia}

Akibat hukum bagi pihak yang beritikad buruk selama negosiasi jual beli adalah kewajiban membayar ganti kerugian, yang disebut tanggung gugat pra kontrak. Dalam membahas tanggung gugat pra kontrak akan dibedakan berdasarkan dampak itikad buruk selama negosiasi terhadap kontrak, yaitu jika mengakibatkan: 1) kontrak tidak sah, dan 2) negosiasi gagal dan kontrak tidak

${ }^{60}$ Cicik Nur Hayati, 'Karakteristik Head of Agreement Menurut Hukum Kontrak Indonesia', Skripsi (Program Sarjana Universitas Airlangga, 2019).[40].

61 ibid.[44].

${ }^{62}$ Sogar Simamora, Op.Cit.[200-201].

63 ibid.

64 ibid.[205]. 
terbentuk sama sekali.

Gambar 1. Tanggung Gugat Pra Kontrak dalam Kerangka Hukum Indonesia

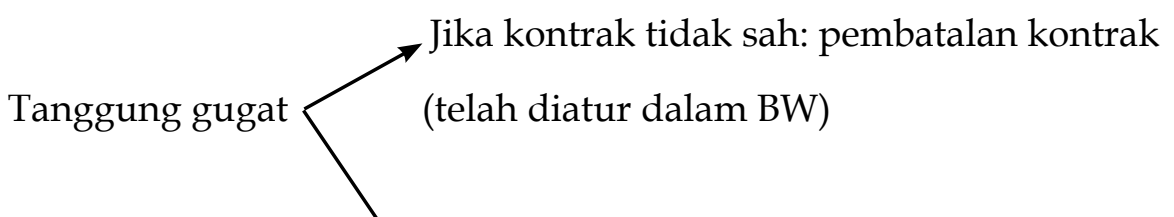

Pra kontrak di Indonesia jika negosiasi gagal: tanggung gugat pra kontrak (belum diatur dalam BW)

Pembatalan Kontrak Sebagai Akibat Hukum Itikad Buruk Selama Negosiasi Jual Beli yang Menyebabkan Kontrak Jual Beli Tidak Sah

Itikad buruk dalam negosiasi dapat menyebabkan kontrak jual beli tidak sah, misalnya tetap menyepakati kontrak yang tidak sah (walaupun mengetahui ketidakabsahannya), menyesatkan lawan pihak, penggunaan paksaan dan penipuan selama negosiasi. Tanggung gugat pra kontrak jenis yang pertama ini telah diatur dalam BW, yaitu mengenai batalnya kontrak akibat melanggar syarat keabsahan kontrak yang diatur dalam Pasal 1320 BW.

Berdasarkan penafsiran a contrario dari pasal 1320 BW, maka bentuk ketidakbasahan kontrak dapat berupa: 1) cacat kehendak, 2) ketidakcakapan, 3) tidak memenuhi objek tertentu, 4) bertentangan dengan causa yang diperbolehkan. Nomor 1 dan 2 berkaitan dengan syarat subjektif, sehingga pelanggaran atas syarat tersebut menyebabkan kontrak dapat dibatalkan (vernietigbaar). ${ }^{65}$ Dapat dibatalkan berarti kontrak tersebut tetap mengikat para pihak sampai diminta pembatalan. ${ }^{66}$ Sedangkan nomor 3 dan 4 berkaitan dengan syarat objektif, sehingga pelanggaran atas syarat tersebut mengakibatkan kontrak batal demi hukum (nietig). ${ }^{67}$ Batal demi hukum berarti dan hakim secara ex officio harus menyatakan kontrak tersebut batal. ${ }^{68}$ Kontrak yang dapat dibatalkan dan batal demi hukum memiliki

\footnotetext{
65 Agus Yudha Hernoko, Op.Cit.[293].

66 J.H. Nieuwenhuis, Op.Cit.[33].

67 Agus Yudha Hernoko, Op.Cit.[293-294].

68 J.H. Nieuwenhuis, Loc.Cit.
} 
konsekuensi yang sama, yaitu kontrak tersebut dianggap tidak pernah ada. ${ }^{69}$

Pasal 1446 BW jo. Pasal 1449 BW mengatur bahwa perikatan (termasuk kontrak jual beli) yang dibuat dengan paksaan, kekhilafan, penipuan, dan dibuat oleh orang yang tidak cakap dapat diajukan pembatalan oleh salah satu pihak. Kemudian Pasal 1451 BW jo. Pasal 1452 BW mengatur bahwa batalnya suatu kontrak jual beli akibat cacat kehendak dan/atau ketidakcakapan mewajibkan para pihak memulihkan keadaan seperti sebelum kontrak dibuat. Sehingga jika kontrak jual beli dibatalkan, maka barang dan harga yang telah diterima wajib dikembalikan. ${ }^{70}$ Pengembalian itu hanya dimungkinkan bila segala hal yang telah diterima masih di tangan lawan pihak dalam jual beli, serta bila lawan pihak telah memakai atau memperoleh manfaat darinya. Misalnya, jika pembeli telah menjual kembali barang yang dibelinya, maka pengembalian barang sudah tidak memungkinkan dan wajib diganti dengan barang yang senilai. ${ }^{71}$ Selain pengembalian pada keadaan semula, berdasarkan Pasal 1453 BW, ganti kerugian berupa biaya, rugi, dan bunga dapat diberikan “jika ada alasan untuk itu". Yang dimaksud frasa tersebut adalah apabila lawan pihak melakukan perbuatan tidak cermat (perbuatan melanggar hukum) e.g. penipuan. $^{72}$

Jika itikad buruk selama negosiasi mengakibatkan kontrak jual beli tidak sah dan diajukan pembatalannya, maka para pihak bertanggung gugat untuk mengembalikan barang dan harga yang telah diterimanya. Bahkan dalam keadaan tertentu, biaya, rugi, dan bunga dapat dituntut kepada pihak yang beritikad buruk. Kewajiban tersebut juga berlaku dalam hal tidak memenuhi syarat objektif. Misalnya, jual beli tanah yang tidak dilakukan dengan akta PPAT mengakibatkan jual beli tersebut batal demi hukum. Jika hal demikian terjadi, maka barang dan harga yang telah diterima para pihak wajib dikembalikan.

${ }^{69}$ ibid.

70 Agus Yudha Hernoko, Op.Cit.[294].

71 ibid.

72 "Menurut yurisprudensi alasan untuk ganti rugi ialah apabila pihak lawan berbuat tidak cermat (perbuatan malanggar hukum). Karena itu dalam penipuan (penyesatan yang disengaja) selalu ada alasan untu pembayaran ganti rugi." Lihat J.H. Nieuwenhuis, Op.Cit.[61]. 
60 Julienna Hartono: Tanggung Gugat Pra...

Dari pemaparan diatas, maka sebagian tanggung gugat pra kontrak telah diatur dalam BW sepanjang mengenai batalnya kontrak akibat melanggar syarat sah kontrak. Pertama, pasal-pasal tersebut mengatur mengenai pembatalan kontrak karena tidak memenuhi syarat sahnya kontrak, dimana tindakan menyepakati kontrak tidak sah (walaupun mengetahui ketidakabsahannya), menyesatkan lawan pihak, menggunakan paksaan dan penipuan selama negosiasi adalah tindakan yang termasuk kedalam kriteria itikad buruk dalam negosiasi jual beli. Kedua, jika hal kontrak batal, maka para pihak wajib mengembalikan keadaan seperti semula. Hal tersebut sesusai dengan ganti kerugian dalam tanggung gugat pra kontrak, yaitu reliance interest. Namun dalam hal pembatalan kontrak akibat cacat kehendak dan ketidakcakapan terdapat kemungkinan pemberian ganti kerugian berupa bunga (keuntungan yang diharapkan/expectation interest) jika ada alasan untuk itu.

\section{Tanggung Gugat Pra Kontrak Sebagai Akibat Hukum Itikad Buruk Selama} Negosiasi Jual Beli yang Menyebabkan Kontrak Jual Beli Gagal Terbentuk

Itikad buruk dalam negosiasi dapat menyebabkan kontrak jual beli gagal terbentuk e.g. menarik diri dari negosiasi tanpa alasan yang jelas, memulai negosiasi tanpa intensi untuk menutup kontrak, dll. Tanggung gugat pra kontrak jenis yang kedua ini belum diatur dalam BW. Walaupun istilah yang digunakan adalah tanggung gugat pra kontrak, tapi harus dimaknai bahwa yang termasuk didalamnya adalah selain yang tercakup oleh pembatalan kontrak.

Karena belum ada pengaturan secara spesifik dalam BW, maka tanggung gugat pra kontrak tunduk pada pengaturan mengenai gugatan ganti kerugian, yang tediri atas wanprestasi dan perbuatan melanggar hukum. Wanprestasi adalah gugatan berdasarkan hubungan kontraktual, ${ }^{73}$ sedangkan perbuatan melanggar hukum adalah tidak perlu didahului hubungan kontraktual, yang penting terdapat perbuatan merugikan yang dilakukan pihak lain dan terdapat

${ }^{73}$ Leonora Bakarbessy dan Ghansam Anand, Op.Cit.[42]. 
kausalitas antara perbuatan dengan kerugian yang dialaminya. ${ }^{74}$

Pertama-tama, dasar gugatan wanprestasi tidak mungkin dapat digunakan, karena kontrak jual beli gagal terbentuk. Selain itu, hukum Indonesia juga seringkali tidak mengakui silent agreement. Sehingga dasar gugatan yang tersisa adalah perbuatan melanggar hukum, yang unsur-unsurnya meliputi:

1. Perbuatan

Perbuatan yang mencerminkan itikad buruk selama negosiasi jual beli telah diuraikan pada bab sebelumnya, misalnya menggunakan paksaan, menarik diri dari negosiasi ketika negosiasi telah mencapai tahap akhir (final stage) tanpa alasan yang jelas, tidak menjelaskan seluruh fakta material berkaitan dengan jual beli, dll. Sehingga unsur perbuatan terpenuhi.

2. Perbuatan tersebut melanggar hukum

Yang dimaksud melanggar hukum salah satunya adalah perbuatan yang bertentangan dengan kewajiban hukum pelaku. Itikad buruk selama negosiasi bertentangan dengan kewajiban hukum pelaku, sehingga unsur melanggar hukum terpenuhi.

3. Kesalahan

Perbuatan yang bertentangan dengan itikad baik selama negosiasi dapat berupa kesengajaan maupun kelalaian. Sehingga unsur kesalahan terpenuhi.

4. Kerugian

Para pihak tentu mengeluarkan biaya selama negosiasi, dari biaya pengacara, biaya perjalanan, sampai membeli asset tertentu. Tentu itikad buruk selama negosiasi menyebabkan kerugian bagi pihak yang telah mengeluarkan biaya selama negosiasi. Sehingga unsur kerugian terpenuhi.

5. Kausalitas antara perbuatan melanggar hukum dengan kerugian yang dialami Perbuatan yang memenuhi kriteria itikad buruk selama negosiasi tentu akan membawa kerugian bagi lawan pihak yang berharap suatu kontrak jual beli akan terwujud. Sehingga unsur kausalitas terpenuhi.

\footnotetext{
${ }^{74}$ Muhammad Zakariah, 'Asas Itikad Baik dalam Negosiasi pada Fase Pra Kontrak', Disertasi (Program Pasca Sarjana Universitas Airlangga, 2013).[94].
} 
Dari pemaparan diatas, perbuatan melanggar hukum dapat digunakan sebagai dasar gugatan culpa in contrahendo, karena memenuhi seluruh unsur perbuatan melanggar hukum. Mengingat nature dasar gugatan ganti kerugian serta kekuatan mengikat perjanjian pendahuluan di Indonesia, maka argumen lain yang mendukung pendapat tersebut antara lain:

a. Terdapat benang merah yang jelas antara gugatan wanprestasi dengan gugatan perbuatanmelanggarhukum. Yangsatugugatan berdasarkanhubungankontraktual, yang kedua bersumber dari perikatan yang lahir karena undang-undang;

b. Berdasarkan analisis pada bab sebelumnya, perjanjian pendahuluan bukanlah sebuah kontrak yang mengikat, karena tidak memenuhi syarat sah kontrak berupa objek tertentu. Sehingga dasar gugatan wanprestasi tidak dapat digunakan;

c. Hukum nasional tidak mengakui silent agreement, sehingga gugatan berdasarkan wanprestasi kemungkinan besar ditolak.

Satu-satunya kemungkinan untuk menggunakan dasar gugatan wanprestasi adalah jika: perjanjian pendahuluan tersebut telah mengatur hak dan kewajiban para pihak untuk berkontrak secara jelas e.g. PPJB Rumah

Dalam sistem hukum Indonesia, ganti kerugian ditentukan berdasarkan dasar gugatan yang digunakan. Dalam gugatan wanprestasi, ganti rugi yang dapat dituntut berupa biaya, rugi, dan bunga. Sedangkan dalam gugatan perbuatan melanggar hukum, ganti rugi yang dapat dituntut berupa kerugian materiil dan immateriil. Jika dikaitkan dengan jenis ganti kerugian dalam hukum kontrak, maka ganti kerugian dalam perbuatan melanggar hukum hanya sebatas reliance interest, sedangkan ganti kerugian dalam wanprestasi terdiri atas reliance interest dan expectation interest. ${ }^{75}$

Sebagaimana telah dianalisa pada subbab sebelumnya, dasar gugatan yang paling tepat untuk gugatan culpa in contrahendo di Indonesia adalah perbuatan melanggar hukum dengan ganti kerugian yang dapat diberikan berupa reliance interest, yaitu kerugian materiil dan immateriil. Adapun dalam gugatan perbuatan melanggar hukum, ganti rugi tidak harus berupa uang. Sehingga disini terbuka

${ }^{75}$ Julija Kirsiene dan Natalja Leonova, Op.Cit.[229]. 
kemungkinan untuk memberikan ganti rugi berupa specific performance, misalnya memaksa para pihak untuk melanjutkan negosiasi. Namun prinsip ganti kerugian dalam tanggung gugat pra kontrak (reliance damage) adalah untuk mengembalikan para pihak ke posisi sebelum negosiasi terjadi. Selain itu, negosiasi yang dipaksakan kemungkinan besar akan gagal. Sehingga ganti rugi berupa memaksa para pihak untuk melanjutkan negosiasi kurang realistis. ${ }^{76}$

Satu-satunya jalan untuk memperoleh ganti kerugian berupa keuntunganyang diharapkan adalah jika mengajukan gugatan berdasarkan wanprestasi. Sebagaimana dijelaskan pada subbab sebelumnya, hal tersebut hanya dimungkinkan bila para pihak telah mengatur hak dan kewajiban secara jelas dalam perjanjian pendahuluan dan belum sampai pada momentum terjadinya jual beli.

Berdasarkan analisis diatas, maka dasar gugatan culpa in contrahendo dan ganti kerugiannya berdasarkan hukum Indonesia adalah:

a. Perbuatan melanggar hukum, dan ganti kerugian yang diberikan hanya sebatas reliance interest;

b. Wanprestasi, jika para pihak menyepakati hak dan kewajiban secara rinci dalam perjanjian pendahuluan (sepanjang belum sampai pada momentum terjadinya jua beli). Ganti kerugian yang diberikan berupa reliance interest beserta expectation interest.

Berdasarkan analisis diatas, dapat disimpulkan bahwa akibat hukum bagi pihak yang beritikad buruk selama negosiasi jual beli adalah kewajiban membayar ganti kerugian kepada pihak yang dirugikan. Istilah yang digunakan adalah tanggung gugat pra kontrak. Tanggung gugat pra kontrak dalam kerangka hukum Indonesia dibagi menjadi dua berdasarkan dampak itikad buruk selama negosiasi terhadap kontrak, yaitu mengakibatkan: 1) kontrak tidak sah, dan 2) negosiasi gagal. Jika itikad buruk selama negosiasi menyebabkan kontrak tidak sah, maka tanggung gugat pra kontraknya telah diatur dalam BW, yaitu mengenai pembatalan kontrak. Sedangkan jika itikad buruk selama negosiasi menyebabkan 
negosiasi gagal, maka pihak yang beritikad buruk bertanggung gugat berdasarkan perbuatan melanggar hukum atau wanprestasi.

Ganti kerugian dari dua jenis tanggung gugat pra kontrak tersebut juga berbeda. Dalam hal kontrak batal, kedua belah pihak wajib mengembalikan barang dan harga yang telah diterimanya (reliance interest), dan bagi pihak yang melakukan perbuatan kurang cermat e.g. penipuan, dapat dihukum untuk membayar bunga (expectation interest). Sedangkan jika menggugat berdasarkan perbuatan melanggar hukum atau wanprestasi, maka hanya pihak yang beritikad buruk saja yang wajib membayar ganti kerugian. Ganti kerugiannya pun bergantung dari dasar gugatan yang digunakan; ganti kerugian untuk perbuatan melanggar hukum sebatas reliance interest (kerugian materiil dan immateriil); ganti kerugian untuk wanprestasi terdiri atas reliance interest dan expectation interest (biaya, rugi, dan bunga). Namun sekali lagi dasar gugatan wanpretasi hanya dapat digunakan jika para pihak menyepakati hak dan kewajiban selama negosiasi secara rinci dalam perjanjian pendahuluan (sepanjang belum sampai pada momentum terjadinya jual beli).

Perbedaan diatas disebabkan karena sebagian tanggung gugat pra kontrak telah diatur dalam BW (jika kontrak tidak sah terbentuk), dan sebagian lagi belum diatur (jika negosiasi gagal dan kontrak tidak terbentuk). Dibawah ini merupakan tabel perbandingan tanggung gugat pra kontrak berdasarkan dampak itikad buruk selama negosiasi terhadap kontrak:

Tabel 1.Tanggung Gugat Pra Kontrak di Indonesia

\begin{tabular}{|c|c|c|}
\hline & Kontrak jual beli tidak sah & Negosiasi gagal \\
\hline Istilah & Pembatalan kontrak & Tanggung gugat pra kontrak \\
\hline Pengaturan & $\begin{array}{l}\text { Telah diatur dalam BW (Pasal } \\
1446 \text { BW- Pasal } 1456 \text { BW) }\end{array}$ & Belum diatur dalam BW \\
\hline $\begin{array}{l}\text { Kewajiban } \\
\text { hukum }\end{array}$ & $\begin{array}{l}\text { Kedua belah pihak wajib } \\
\text { mengembalikan barang dan } \\
\text { harga yang telah diterima }\end{array}$ & $\begin{array}{l}\text { Hanya pihak yang beritikad buruk } \\
\text { yang membayar ganti kerugian }\end{array}$ \\
\hline $\begin{array}{l}\text { Ganti } \\
\text { kerugian }\end{array}$ & $\begin{array}{l}\text { Reliance interest, dan expectation } \\
\text { interest jika ada alasan untuk itu } \\
\text { e.g. menggunakan penipuan }\end{array}$ & $\begin{array}{l}\text { Tergantung dasar gugatan yang } \\
\text { digunakan: } \\
\text { - } \quad \begin{array}{l}\text { Perbuatan melanggar hukum } \rightarrow \\
\text { reliance interest }\end{array} \\
\text { - Wanprestasi } \rightarrow \text { reliance interest } \\
\text { dan expectation interest }\end{array}$ \\
\hline
\end{tabular}




\section{Kesimpulan}

Dari analisa diatas, maka telah diperoleh kriteria negosiasi dengan itikad buruk dalam jual beli yang terdiri atas:

1. Menyepakati kontrak yang tidak sah;

2. Dengan lalai atau sengaja membuat pernyataan yang menyesatkan lawan pihak;

3. Menggunakan paksaan, penipuan, dan/atau menyalahgunakan keadaan selama negosiasi;

4. Tidak serius dalam membuat suatu penawaran;

5. Melakukan kesalahan dalam menyampaikan penawaran;

6. Mengetahui atau seharusnya mengetahui ketidakmungkinan pelaksanaan suatu kontrak, namun tetap melanjutkan negosiasi;

7. Menarik diri dari negosiasi ketika negosiasi telah mencapai tahap akhir (final stage) dan tanpa alasan yang jelas;

8. Penjual tidak menjelaskan seluruh fakta material berkaitan dengan jual beli;

9. Pembeli tidak meneliti fakta material berkaitan dengan jual beli;

10. Memasuki atau melanjutkan negosiasi tanpa bermaksud untuk mencapai kontrak dengan lawan pihak;

11. Membocorkan informasi rahasia yang telah diberikan oleh lawan pihak selama negosiasi;

12. Menunda-nunda jual beli (delay in concluding contract).

Adapun kriteria tersebut tidak boleh bersifat statis, namun harus selalu berkembang secara dinamis mengikuti nilai-nilai yang hidup dalam masyarakat.

Akibat hukum bagi pihak yang beritikad buruk selama negosiasi jual beli adalah wajib membayar ganti kerugian, yang disebut tanggung gugat pra kontrak. Tanggung gugat pra kontrak dalam hukum Indonesia dibagi menjadi dua berdasarkan dampak itikad buruk selama negosiasi terhadap kontrak; jika mengakibatkan kontrak tidak sah maka, sesuai ketentuan Pasal 1446 BW-Pasal 1456 BW, kontrak menjadi batal dan kedua belah pihak wajib mengembalikan barang dan harga yang telah diterimanya (reliance interest), dan jika ada alasan untuk itu ganti kerugian expectation interest dapat diberikan; jika mengakibatkan negosiasi gagal maka ganti kerugian diperoleh dengan mengajukan gugatan berdasarkan perbuatan melanggar hukum atau wanprestasi (jika para pihak menyepakati hak dan kewajiban secara jelas dalam perjanjian pendahuluan). Ganti kerugiannya pun bergantung dasar gugatan yang digunakan; jika menggugat berdasarkan perbuatan melanggar hukum, maka ganti kerugian sebatas reliance interest; jika 
66 Julienna Hartono: Tanggung Gugat Pra...

menggugat berdasarkan wanprestasi,ganti kerugian berupa reliance interest dan expectation interest.

\section{Daftar Bacaan}

\section{Buku}

Agus Yudha Hernoko, Hukum Perjanjian: Asas Proporsionalitas dalam Kontrak Komersial, Cet.IV (Prenadamedia Group 2014).

Arthur S. Hartkamp, Contract Law in the Netherlands, Edisi II (Kluwer Law International 2015).

Erni Agustin, The Duty of Good Faith and Pre-Contractual Liability (A Comparative Study)(Airlangga University Press 2013).

H. Salim HS., H. Abdullah, dan Wiwiek Wahyuningsih, Perancangan Kontrak dan Memorandum of Understanding (MoU), Cet.IV (Sinar Grafika 2008).

J.H. Nieuwenhuis, Pokok-Pokok Hukum Perikatan (terjemahan Djasadin Saraghi) (Universitas Airlangga 1985).

Leonora Bakarbessy dan Ghansam Anand, Buku Ajar Hukum Perikatan (Zifatama Jawara 2018).

Natsir Asnawi, Aspek Hukum Janji Prakontrak: Telaah dalam Kerangka Pembaruan Hukum Kontrak di Indonesia (UII Press 2017).

Peter Mahmud Marzuki, Penelitian Hukum, Cet. VII (Kencana 2011) (selanjutnya disingkat Peter Mahmud Marzuki I).

Peter Mahmud Marzuki, Pengantar Ilmu Hukum, Cet.VIII (Kencana 2015) (selanjutnya disingkat Peter Mahmud Marzuki III).

Philipus M. Hadjon [et al.], Argumentasi Hukum, Cet. VI (Gadjah Mada University Press 2017).

Ridwan Khairandy, Itikad Baik dalam Kebebasan Berkontrak, Cet.II (Fakultas Hukum Universitas Indonesia 2004).

Sogar Simamora, Hukum Kontrak: Prinsip-Prinsip Hukum Kontak Pengadaan Barang dan Jasa Pemerintah di Indonesia (LaksBang PRESSindo 2017).

Subekti, Aneka Perjanjian, Cet.XI (Citra Aditya Bakti 2014) (selanjutnya disingkat 
Subekti II).

Suharnoko, Hukum Perjanjian: Teori dan Analisa Kasus, Cet.III, Edisi I (Grafika 2004).

Taryana Soenandar, Prinsip-Prinsip UNIDROIT sebagai Sumber Hukum Kontrak dan Penyelesaian Sengketa Bisnis Internasional, Cet.I (Sinar Grafika 2004).

Terry Hutchinson, Researching and Writing in Law ( Lawbook Co 2002).

\section{Jurnal}

Albert H. Choi dan George Triantis, ‘Designing and Enforcing Preliminary Agreements' (2020) 3 Texas Law Review.

Chuanyang Ding, 'The Doctrine of Precontractual Liability Under Chinese Law : A Comparative Outlook' (2019) 27 European Review of Private Law.

Claude Alavoine, Ferkan Kaplanseren dan Frederic Teulon, 'Teaching (and Learning) Negotiation: Is There Still A Room for Innovation?' (2014) 18 International Journal of Management \& Information System.

E. Allan Fransworth, 'Precontractual Liability and Preliminary Agreements: Fair Dealing and Failed Negotiations' (1987) 87 Columbia Law Review.

Faizal Kurniawan [et al.] 'Unsur Kerugian dalam Unjust Enrichment untuk Mewujudkan Keadilan Korektif (Corrective Justice)’ (2018) 33 Yuridika.

Friedrich Kessler dan Edith Fine, 'Culpa in Contrahendo, Bargaining in Good Faith, and Freedom of Contract: a Comparative Study' (1964) 77 Harvard Law Review.

Julija Kirsiene dan Natalja Leonova, 'Qualification of Pre-Contractual Liability and The Value of Loss Opportunity as A Form of Losses' (2009) 1 Jurisprudencija.

Najib Hage-Chahine, 'Culpa in Contrahendo in European Private International Law: Another Look at Article 12 of the Rome II Regulation' (2012) 32 Northwestern Journal of International Law and Business.

Rodrigo Novoa, 'Culpa in Contrahendo: A Comparative Law Study: Chilean Law and The United Nations Convention on Contracts for The International Sales of Goods' (2005) 22 Arizona Journal of International and Comparative Law.

\section{Skripsi}

Cicik Nur Hayati, Karakteristik Head of Agreement Menurut Hukum Kontrak Indonesia, Skripsi (Program Sarjana Universitas Airlangga, 2019). 
Ichsania Saputri, Doktrin Culpa in Contrahendo (Prinsip dan Penerapannya dalam Tanggung Gugat Hubungan Pra-Kontraktual), Skripsi (Program Sarjana Universitas Airlangga, 2013).

\section{Disertasi}

Muhammad Zakariah, Asas Itikad Baik dalam Negosiasi pada Fase Pra Kontrak, Disertasi (Program Pasca Sarjana Universitas Airlangga, 2013).

\section{Makalah}

John Y. Gotanda, Damages in Lieu of Performance because of Breach of Contract, Working Paper Series pada Villanova University Charles Widger School of Law (Villanova University Charles Widger School of Law 2006).

R.J.P Kottenhagen, From Freedom of Contract to Forcing Parties to Agreement, Address to the Annual Meeting of the European American Consortium for Legal Education (European American Consortium for Legal Education 2005).

\section{Laman}

Brainy Quote, 'Glenn Danzig Quotes' (Brainy Quote, 2020)<https://www. brainyquote.com/quotes/glenn_danzig_274256> diakses pada tanggal 13 Oktober 2020.

John Cartwright dan Martjin W. Hesselink,'Precontractual Liability In European Private Law: Conclusions' (Cambridge University Press ,2008)<https:// www.researchgate.net/publication/228218852_Precontractual_Liability_ in_European_Private_Law_Conclusions>.diakses pada tanggal 5 Desember 2020.

\section{Perundang-undangan}

Staatsblad No. 23 Tahun 1847 tentang Burgerlijk Wetboek Voor Indonesie

How to cite: Julienna Hartono, ‘Tanggung Gugat Pra Kontrak Transaksi Jual Beli Berdasar Negosiasi dengan Itikad Buruk' (2021) Vol. 4 No. 1 Notaire. 